\title{
Regulation of pancreatic islet cell survival and replication by $\gamma$-aminobutyric acid
}

\author{
B. Ligon • J. Yang • S. B. Morin • M. F. Ruberti • \\ M. L. Steer
}

Received: 8 November 2006 / Accepted: 17 December 2006 / Published online: 22 February 2007

(C) Springer-Verlag 2007

\begin{abstract}
Aims/hypothesis Pancreatic islets have evolved remarkable, though poorly understood mechanisms to modify beta cell mass when nutrient intake fluctuates or cells are damaged. We hypothesised that appropriate and timely adjustments in cell number occur because beta cells release proliferative signals to surrounding cells when stimulated by nutrients and 'bleed' these growth factors upon injury.

Materials and methods In rat pancreatic islets, we measured DNA content, insulin content, insulin secretion after treatment, immunoblots of apoptotic proteins and the uptake of nucleoside analogues to assess the ability of $\gamma$ aminobutyric acid (GABA), which is highly concentrated in beta cells, to act as a growth and survival factor. This focus is supported by work from others demonstrating that
\end{abstract}

\section{B. Ligon · M. F. Ruberti}

Department of Neuroscience,

Tufts University School of Medicine,

136 Harrison Ave.,

Boston, MA 02111, USA

\section{B. Ligon}

Department of Neurology, Tufts University School of Medicine,

Boston, MA, USA

J. Yang $\cdot$ S. B. Morin $\cdot$ M. F. Ruberti

Molecular Cardiology Research Institute,

Tufts-New England Medical Center,

Boston, MA, USA

B. Ligon · M. L. Steer

Department of Surgery, Tufts-New England Medical Center,

Boston, MA, USA

B. Ligon $(\bowtie)$

Mitokine Bioscience,

P.O. Box 275, Hancock, ME 04640, USA

e-mail: b.ligon@mitokine.com
GABA increases cell proliferation in the developing nervous system, acts as a survival factor for differentiated neurons and, interestingly, protects plants under stress.

Results Our results show that DNA, insulin content and insulin secretion are higher in freshly isolated islets treated with GABA or GABA B receptor agonists. Exposure to GABA upregulated the anti-apoptotic protein B-cell chronic lymphocytic leukaemia XL and limited activation of caspase 3 in islets. The cellular proliferation rate in GABA-treated islets was twice that of untreated controls.

Conclusions/interpretation We conclude that GABA serves diverse purposes in the islet, meeting a number of functional criteria to act as an endogenous co-regulator of beta cell mass.

Keywords Apoptosis · Beta cells · GABA .

GABA B receptor Insulin secretion · Islet mass .

Islet survival $\cdot$ Pancreatic islets $\cdot$ Proliferation

$\begin{array}{ll}\text { Abbreviations } \\ \text { BCL } & \text { B-cell chronic lymphocytic leukaemia } \\ \text { EC }_{50} & \text { median effective concentration } \\ \text { GABA } & \gamma \text {-aminobutyric acid } \\ \text { GBR1 } & \text { GABA B receptor subunit 1 } \\ \text { GBR1-C } & \text { C-terminus of GABA B receptor subunit 1 } \\ \text { GBR1-N } & \text { N-terminus of GABA B receptor subunit 1 } \\ \text { GBR2 } & \text { GABA B receptor subunit } 2\end{array}$

\section{Introduction}

To maintain requisite hormonal stores, beta cells of the pancreatic islet are continuously remodelled through cell death and division. If healthy individuals increase nutrient 
intake, for example, beta cell turnover is shifted toward expansion [1-3]. Significant increases in cell division are also observed when beta cells are injured [4, 5]. Present understanding of how injury or increased nutrients convert to signals enhancing cell mass is limited. The lineage studies by Dor et al. provided critical data suggesting that the mature beta cell, rather than an undifferentiated 'progenitor,' is central to this routine renewal process [6]. Nevertheless, much remains to be determined of how signals converge to initiate beta cell turnover under normal or adverse conditions.

Ideal regulators of islet cell renewal would be mediators of growth secreted by beta cells on nutrient stimulation and present at sufficiently high concentrations to act locally if leaked when beta cells are injured. Beta cells contain two candidates that meet these criteria, insulin and $\gamma$-aminobutyric acid (GABA). Much is known about the systemic role of insulin signalling in growth, and recent evidence also suggests that insulin mediates local beta cell growth responses [4, 7]. In addition, mounting evidence implicates GABA, predominantly viewed as a neurotransmitter, as an evolutionarily conserved regulator of survival and growth processes [8]. In plants, both GAD, as the enzyme of GABA synthesis, and GABA are upregulated with changes in $\mathrm{pH}$ or temperature [9] or with ripening [10], suggesting a role in plant protection. Additional evidence supports a role for GABA in plant development [11]. Similarly, GABA appears to be a conserved regulator of survival and growth in animals, having been shown to induce the maturation of red abalone from larvae to adults [12] and stimulate proliferation in regions of neurogenesis in the mammalian brain [13]. GABA also participates in neuronal migration [14], dendritic arborisation [15], the survival of striatal neurons [16] and proliferation of cerebellar neurons [17]. Accordingly, the presence of GAD and GABA signalling in both plants and animals suggests a signalling system conserved over billions of years [18].

In animals, GABA is synthesised and stored in peripheral organs as well as in the central nervous system. The highest concentration of GABA peripherally is found in beta cells of the pancreatic islet [19], at levels comparable with those observed in GABAergic brain nuclei [19, 20]. Work by others indicates GABA is released from beta cells in response to nutrients and depolarisation through a calcium-regulated secretion pathway [21-24]. Using electrophysiology, Wendt et al. estimated that concentrations of GABA within the islet reach levels sufficient for GABA to act as a paracrine signal [25]. Presently, however, information is limited concerning the functional consequence of GABA in pancreatic islets. GABA has been reported to act in part to inhibit islet alpha cell activity and glucagon secretion [21, 24, 25], but the available evidence is conflicting with regard to the role of GABA in regulating insulin release from beta cells [26, 27]. Here we have examined the alternative possibility that GABA acts through receptor-mediated pathways to regulate growth and/or survival, as observed in other systems. This hypothesis is supported by the fact that the low concentrations necessary to modulate secretion locally are incongruent with the high concentrations of GABA present in beta cells.

The effects of GABA are mediated through three receptor types, ionotropic GABA $\mathrm{A}$ and GABA $\mathrm{C}$ receptors and metabotropic GABA B receptors. GABA B receptors contain two known subunits, GABA B receptor subunit 1 (GBR1; includes six splice variants) and GABA B receptor subunit 2 (GBR2), which heterodimerise to activate downstream effectors, in part via $G$ protein-coupled signal transduction pathways. The GABA B receptor also contains a carboxyterminal coiled-coiled domain shown to interact with transcription factors $[28,29]$ that provides a means to influence cellular responses independently of $\mathrm{G}$ proteins [30].

The present studies were undertaken to test whether physiological concentrations of exogenous GABA regulate cell replication or survival properties in freshly isolated rat pancreatic islets. The process of islet isolation, an important component of therapeutic strategies now under development for functional reconstitution of islets in diabetes, is known to increase cell death through apoptosis [31]. We found that GABA could prevent this cell loss and influence islet cell plasticity. We therefore used pharmacological agents and protein immunoblots to identify the receptor subtypes involved in this process and the downstream mediators of receptor signalling. Overall, the results support the hypothesis that GABA, released by islet cells during nutrient stimulation or due to cell injury, may act in an autocrine/paracrine manner to support or regenerate the number of islet cells necessary to maintain glucose homeostasis. This local, immediate signal would allow for rapid and efficient modification of islet cell number in response to increases in nutrient intake or acute cellular injury.

\section{Materials and methods}

Materials Fibrinogen, GABA and baclofen were from Sigma (St Louis, MO, USA), SCH50911 (a GABA B receptor antagonist) was from Tocris (Ellisville, MO, USA) and bromodeoxyuridine from Roche (Indianapolis, IN, USA). The CyQuant assay was from Molecular Probes (Eugene, OR, USA). Medium 199/Earle's balanced salts was from Invitrogen (Carlsbad, CA, USA). Insulin radioimmunoassay reagents were from MP Biomedicals (ICN, Irvine, CA, USA). Immunoblot protein was measured using Micro BCA (bicinchoninic acid) reagents from Pierce (Rockford, IL, USA). C-terminus of GBR1 (GBR1-C) and GBR2 primary antisera were from Chemicon (Temecula, 
CA, USA). Antiserum to N-terminus of GBR1 (GBR1-N) was raised in rabbit by Research Genetics (Carlsbad, CA, USA) using the 16 amino acid peptide corresponding to residues 201-216 of the GABA B receptor 1a subunit. Mouse anti-BrdU was from Becton Dickinson (San Jose, CA, USA). The secondary antisera rhodamine red-X antirabbit and $\mathrm{Cy} 2$ anti-guinea pig were from Jackson ImmunoResearch (West Grove, PA, USA). For immunoblotting, rabbit anti-B-cell chronic lymphocytic leukaemia (BCL)-XL was from Cell Signaling Technology (Beverly, MA, USA) and horseradish peroxidase-coupled anti-rabbit antiserum was from Bio-Rad (Hercules, CA, USA). The protease inhibitor was from Roche. Hepatocyte growth factor was from R \& D Systems (Minneapolis, MN, USA).

Islet isolation and incubation Islets were isolated according to the method of Gotoh et al. [32] from pancreata of 150 200-g male Sprague-Dawley rats that were anaesthetised (pentobarbital $100 \mathrm{mg} / \mathrm{kg}$ i.p.) and subsequently killed. Islets were then size-selected to be $<200 \mu \mathrm{m}$ in diameter. Animals were maintained according to the rules and standards of the $\mathrm{NIH}$ and the Institutional Animal Care and Use Committee of Tufts University School of Medicine. To measure DNA content, islets were manually divided (while on ice) and placed in groups of $\sim 80$ islets per well in 96-well tissue culture plates. The islets were plated in contact with each other and in a small volume to allow adherence before the addition of medium to $200 \mu$ l. They were maintained at $37^{\circ} \mathrm{C}$, in a $\mathrm{CO}_{2}$ incubator, in M199 medium with Earle's balanced salts, $38 \mathrm{mmol} / 1 \mathrm{NaHCO}_{3}, 5.6 \mathrm{mmol} / \mathrm{l}$ HEPES, $10 \%$ normal calf serum and $10 \mathrm{mmol} / 1$ nicotinamide. For quantification of ${ }^{3} \mathrm{H}$-labelled thymidine incorporation, 35 hand-picked, freshly prepared islets were secured within a fibrin gel as described by Beattie et al. [33]. Islets were kept on ice during selection and plating. Once the fibrin gel was firm, M199 medium, modified as described above, was added to a final volume of $100 \mu \mathrm{l}$. To quantify BrdU labelling of islet cell nuclei, 40-50 freshly isolated islets were suspended in $10 \mu \mathrm{l}$ of M199 medium with additives as listed above and allowed to attach to tissue culture treated 96-well plates, after which $200 \mu$ of the modified M199 medium was added.

Measurement of DNA content Freshly isolated islets were incubated for $60 \mathrm{~min}$ with GABA $(100 \mu \mathrm{mol} / \mathrm{l}), S$-baclofen $(100 \mu \mathrm{mol} / \mathrm{l})$ or GABA plus the GABA B receptor antagonist SCH $50911(100 \mu \mathrm{mol} / \mathrm{l})$ or left untreated. These reagent concentrations are standard for all known GABA receptors, which are low-affinity and require micromolar amounts for saturation [34]. Unless otherwise stated, the glucose concentration in the suspending medium was $5.6 \mathrm{mmol} / \mathrm{l}$. The islets were transferred to medium lacking test agents and incubated for an additional $3.5 \mathrm{~h}$ at $37^{\circ} \mathrm{C}$. Incubation with $2 \times$ lysis buffer was at $37^{\circ} \mathrm{C}$ overnight, followed by freezing and thawing, and trituration through a 27-gauge needle. DNA content was quantified fluorometrically using the CyQuant assay according to the manufacturer's instructions.

Immunohistochemistry To reproduce conditions of islet isolation and enhance receptor expression, $6 \mathrm{ml}$ of medium M199 were infused into the pancreatic duct of an anaesthetised rat. The pancreas was removed and incubated for $30 \mathrm{~min}$ in a $50-\mathrm{ml}$ tube in a $37^{\circ} \mathrm{C}$ water-bath and agitated to simulate islet isolation, but in the absence of collagenase. The pancreas was fixed in neutral-buffered $2 \%$ paraformaldehyde for $30 \mathrm{~min}$, then cryoprotected for quick freezing and sectioning at $8 \mu \mathrm{m}$. Sections were blocked for $1 \mathrm{~h}$ in PBS containing 3\% normal goat serum and $0.2 \%$ triton, washed with PBS and incubated overnight at $4{ }^{\circ} \mathrm{C}$ with primary antibodies diluted to the following concentrations: insulin $(1: 100)$, GBR1-C $(1: 2000)$ GBR1-N (1:2500) and GBR2 1:1,000. The sections were washed and incubated with secondary antibodies for $20 \mathrm{~min}$ at room temperature.

Measurement of insulin content Islet cell lysate $(100 \mu \mathrm{l})$ was frozen for measurement of total cellular insulin. The lysate was diluted 1:7,500 in PBS and $100 \mu$ of that dilution (or standards) were added to tubes lined with antibodies to insulin. Manufacturer-supplied buffer (Valeant Pharmaceuticals) containing ${ }^{125}$ I-labelled insulin was added to each tube to bring the final volume to $1 \mathrm{ml}$. The tubes were incubated at room temperature overnight and washed, after which bound ${ }^{125}$ I-labelled insulin was assayed on a gamma-counter.

Measurement of insulin secretion after treatment Freshly isolated small islets (20-30) were plated in clusters in 60-90 $\mu \mathrm{l}$ respectively of M199 medium in half-diameter 96-well plates. Islets were incubated for $60 \mathrm{~min}$ with test reagents, as above, or left untreated. After incubation, the medium was changed to $\mathrm{KRB}$ with $2.8 \mathrm{mmol} / \mathrm{l}$ glucose for washing and equilibration. The low-glucose medium was removed and fresh $\mathrm{KRB}$ with $11 \mathrm{mmol} / \mathrm{l}$ glucose was added for $60 \mathrm{~min}$ of islet incubation at $37^{\circ} \mathrm{C}$ in a $5 \% \mathrm{CO}_{2}$ incubator. The supernatant fraction was removed for measurement of insulin by RIA as described above.

Western blot For immunoblotting of BCL-XL, freshly isolated islets were incubated at the designated times, homogenised in radioimmuno-precipitation buffer (50 mmol/1 Tris HCl, $150 \mathrm{mmol} / \mathrm{l} \mathrm{NaCl}, 1 \% \mathrm{NP}-40,0.5 \%$ sodium deoxycholate, $0.1 \%$ SDS), subjected to SDSpolyacrylamide gel electrophoresis (75 $\mathrm{g}$ g/lane, $10 \%$ gels), transferred to nitrocellulose membranes and probed with 
anti-BCL-XL antibody at 1:1,000 dilution. The same methods were used for the immunoblot of cleaved caspase 3 , except that polyvinylidene difluoride membranes were used and probed with anti-caspase 3 antibody at 1:3500 dilution. Chemiluminescence was detected with reagents (SuperSignal West Femto; Pierce).

${ }^{3}$ H-labelled thymidine incorporation Freshly isolated islets in fibrin clots [33] were incubated for $1 \mathrm{~h}$ at $37^{\circ} \mathrm{C}$ in $\mathrm{M} 199$ medium containing varying concentrations of either baclofen or GABA along with $0.037 \mathrm{MBq} / \mathrm{ml}^{3} \mathrm{H}$-labelled thymidine. The medium was replaced with medium plus ${ }^{3} \mathrm{H}$-labelled thymidine but lacking GABA and baclofen and the islets incubated for an additional $3.5 \mathrm{~h}$ at $37^{\circ} \mathrm{C}$. For timedependent experiments, the duration of islet incubation with GABA in medium with $0.037 \mathrm{MBq} / \mathrm{ml}^{3} \mathrm{H}$-labelled thymidine varied between 0 and $90 \mathrm{~min}$. The islets were then incubated without test reagents in medium M199 with $0.037 \mathrm{MBq} / \mathrm{ml}^{3} \mathrm{H}$-labelled thymidine for a total of $4.5 \mathrm{~h}$. Islets were washed with PBS and $100 \mu$ cold 5\% trichloroacetic acid was added for $20 \mathrm{~min}$ to remove unincorporated label. The islets, in fibrin clots, were lysed by overnight incubation in $100 \mu \mathrm{l} \mathrm{NaOH}(1 \mathrm{~mol} / \mathrm{l})$. A shorter incubation time resulted in incomplete lysis. $\mathrm{NaOH}$ neutralisation was with $100 \mu \mathrm{HCl}(1 \mathrm{~mol} / \mathrm{l})$. Radioactivity was quantified using a liquid scintillation counter (Beckman, Fullerton, CA, USA).

Bromodeoxyuridine labelling Freshly isolated islets were incubated with $30 \mu \mathrm{mol} / 1 \mathrm{BrdU}$ in the presence or absence of GABA $(100 \mu \mathrm{mol} / \mathrm{l})$ or hepatocyte growth factor $(20 \mathrm{ng} / \mathrm{ml})$ for $1 \mathrm{~h}$. The culture medium was replaced with fresh medium lacking both GABA and hepatocyte growth factor. After overnight culture, the islets were washed, immersed in optimal cutting temperature Tissue-Tek (Bayer, Pittsburgh, PA, USA) and quick-frozen in moulds. Sections $(8 \mu \mathrm{m})$ were post-fixed for $10 \mathrm{~min}$ in acetone, followed by washing in PBS and denaturation by treating for $5 \mathrm{~min}$ with PBS containing $0.5 \%$ triton and subsequent exposure to $1.5 \mathrm{mmol} / 1 \mathrm{HCl}$ for $30 \mathrm{~min}$. Sections were blocked, exposed to mouse anti-BrdU 1:50 for $1 \mathrm{~h}$, washed and antibody labelling detected using $\mathrm{Cy} 2$ anti-mouse secondary antibodies (1:50 dilution). Nuclei were counterstained with propidium iodide $(0.0001 \%)$.

Analysis of data The results reported in this manuscript reflect the findings of three or more experiments. The significance of changes was determined by one-way ANOVA followed by Tukey's multiple comparison test for significance or when sample size was less than ten (baclofen dose-response experiments) the Kruskal-Wallis test followed by Dunn's multiple comparison test. Chi-square analysis was used to determine the significant differences of treated and untreated BrdU-labelled nuclei with significance defined as a change associated with a $p$ value of less than 0.05 .

\section{Results}

Islets treated with $G A B A$ and $G A B A B$ agonists maintain $D N A$ content As shown in Fig. 1, incubation of freshly isolated islets in GABA-free medium for $4.5 \mathrm{~h}$ resulted in a $19.4 \pm 3.6 \%$ decrease in islet DNA, equivalent to the cell loss observed by others [31]. In contrast, islets incubated for the initial 60 min with GABA or the GABA B receptor agonist baclofen and then subsequently incubated in GABA-free medium retain the same DNA content as measured at time 0 . This maintenance of islet DNA content was not observed when the GABA B receptor antagonist $\mathrm{SCH} 50911$ was included with GABA in the incubation mixture (Fig. 1a). These experiments suggest that GABA, acting via GABA B receptors, activates cellular programmes capable of protecting the cells normally vulnerable to injury induced by islet isolation.

$G A B A$ and $G A B A B$ receptor agonists preserve islet insulin content To assess the sensitivity of the beta cell subpopulation to GABA, we measured the effect of GABA treatment on maintaining islet insulin content (Fig. 1b). In these experiments we measured total insulin content of islet lysates at the end of the culture period and compared that to insulin content of islets frozen immediately after islet isolation (time 0). Islets left untreated had $14 \pm 6 \%$ more insulin after $4.5 \mathrm{~h}$ of culture than islets at time 0 . Islets exposed to GABA during the first hour of the $4.5 \mathrm{~h}$ culture period contained $54 \pm 14 \%$ more insulin than control islets frozen at time 0 (Fig. 1b). Similarly, islets treated for $1 \mathrm{~h}$ with the GABA B agonist baclofen contained $45 \pm 9 \%$ more insulin than 0 time controls. These results suggest that GABA, acting via GABA B receptors, can regulate individual beta cell insulin content and/or beta cell mass.

Pretreatment of islets with GABA and GABA B receptor agonists enhances insulin secretion To further evaluate the effects of GABA specifically on beta cells, freshly isolated islets were cultured in the presence of GABA, the GABA B receptor agonist baclofen, GABA plus the receptor antagonist SCH 50911 or without treatment. After $1 \mathrm{~h}$, islets were washed and equilibrated in $\mathrm{KRB}$ with $2.8 \mathrm{mmol} / \mathrm{l}$ glucose and then stimulated with $\mathrm{KRB}$ with $11 \mathrm{mmol} / \mathrm{l}$ glucose. After an additional $1 \mathrm{~h}$ of glucose stimulation, supernatant fractions were removed for RIA of secreted insulin. The islets were lysed for normalisation to DNA content. GABA-treated islets secreted $31.45 \pm 9 \%$ more insulin than controls (Fig. 1c). The increase was not 
a
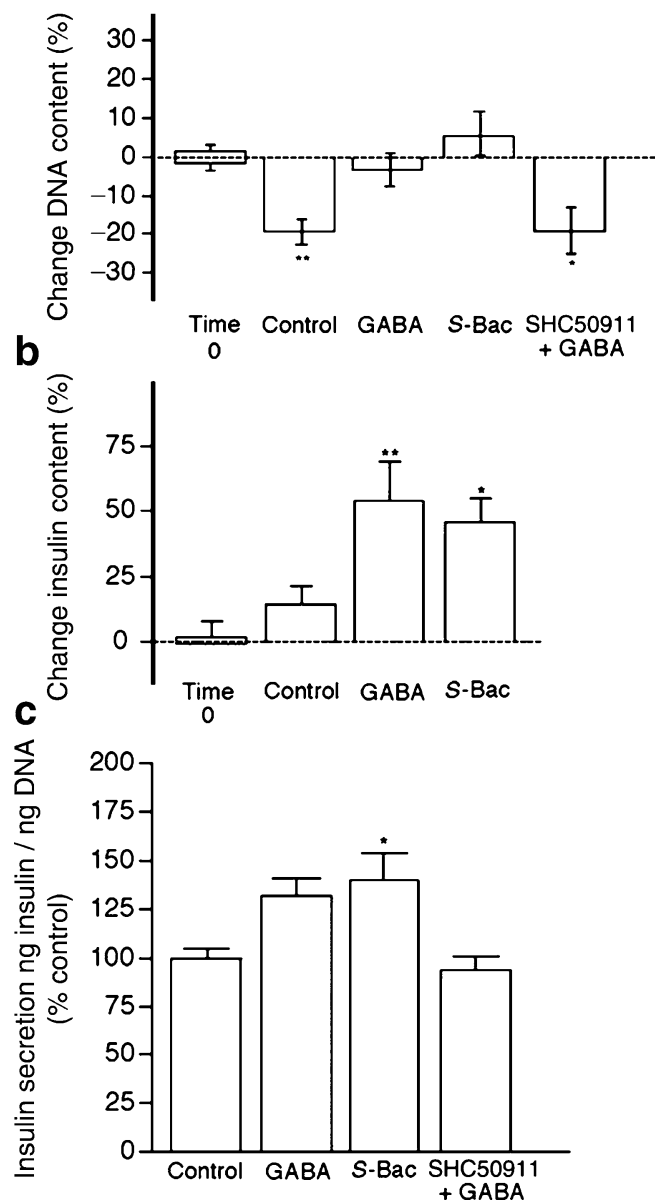

Fig. 1 GABA treatment protects islet DNA and insulin content and improves insulin secretion. Freshly prepared islets were cultured with or without GABA $(100 \mu \mathrm{mol} / \mathrm{l}), S$-baclofen $(S$-Bac $)(100 \mu \mathrm{mol} / \mathrm{l})$ or SCH50911 + GABA for $60 \mathrm{~min}$ and then placed in fresh medium lacking these agents for another $3.5 \mathrm{~h}$. a DNA content was measured from islet lysates. Values are mean and SEM for five experiments and eight to 19 independent measurements. Insulin content (b) was also measured from islet lysates after no treatment, $1 \mathrm{~h}$ of GABA or $S$ baclofen treatment and $4.5 \mathrm{~h}$ total culture. Values are mean and SEM for three to five experiments and seven to 24 independent measurements. Statistical analysis was by one-way ANOVA. c Freshly prepared islets were cultured as above. Islets were washed and equilibrated in KRB with $2.8 \mathrm{mmol} / 1$ glucose. Low glucose KRB was removed and replaced with KRB with $11 \mathrm{mmol} / 1$ glucose for $60 \mathrm{~min}$ incubation at $37^{\circ}$. Supernatant fractions were removed for analysis of insulin secretion. Values are mean and SEM for three to five experiments and 11-25 independent measurements. $* p<0.05$ and $* *$ $p<0.01$ compared with time 0 point control samples or control samples

statistically significant by one-way ANOVA, possibly due to the fact that insulin secretion was expressed as a ratio to DNA content, which the data suggested to have been maintained to a greater degree than controls. Islets treated with baclofen secreted $39 \pm 14 \%$ more insulin than controls. Insulin secretion from untreated control islets was the same as that from islets treated with the antagonist to GABA B receptors + GABA.
GABA B receptors subunits are present on beta cells Our method of detecting GABA B receptors involved immunohistochemistry using antiserum that labels GBR1-C, our own anti-GBR1-N-terminal antiserum and antiserum to GBR2. The C-terminus antiserum, targeting full-length GBR-1, evenly labels all cells in moderate to small-sized islets, including cells that co-label for insulin (Fig. 2a-c). Cells that do not label for insulin also show receptor expression. Both GBR1 and GBR2 were immunohistochemically detected in rat islets. In some islets, as in the nervous system [34], labelling for both the GBR1 and GBR2 subunits appeared equal (Fig. 3a-c), while in others labelling for GBR2 appeared greater than for GBR1 (Fig. 3e-g).

GABA-treated islets upregulate the anti-apoptotic protein $B C L-X L$ and reduce activation of pro-apoptotic caspase 3 The process of islet isolation is known to cause a percentage of cells to die by apoptosis [31]. Therefore, to investigate possible mechanisms for GABA-induced cell survival, we evaluated the ability of GABA to regulate the anti-apoptotic proteins BCL2 and BCL-XL. No GABA effects on BCL2 levels were observed in freshly isolated islets, but GABA influenced BCL-XL production in a time-dependent manner. BCL-XL levels were increased over controls after $60 \mathrm{~min}$ of GABA treatment (180 min after pancreatectomy) and remained at higher levels $1 \mathrm{~h}$ after GABA was removed (Fig. 4a,b). Although these changes appear to be quite rapid, the cascade signalling cell death or cell survival is likely to be activated when the pancreas is perfused and blood supply is terminated during the islet isolation process. The isolation and plating of islets provides an additional $2 \mathrm{~h}$ for protein synthesis. We also point out that the reagents used detect changes in protein levels in the femtogram $\left(\mathrm{g} \times 10^{-15}\right)$ range. To further examine the possibility that GABA might regulate islet cell apoptosis, the effect of GABA treatment on the activation of the proapoptotic protein caspase 3 was evaluated. Freshly isolated islets treated with GABA showed substantially less cleaved, activated caspase 3 than untreated controls (Fig. 4c,d). These results support the findings of increased cell survival in GABA-treated islets as measured by DNA content and suggest that one mechanism effecting this is regulation of pro- and anti-apoptotic proteins.

GABA stimulates pancreatic islet cell proliferation In addition to influencing cell survival, GABA also increases the incorporation of ${ }^{3} \mathrm{H}$-labelled thymidine into islet cell DNA (Fig. 5), suggesting a role in cell replication. Halfmaximal stimulation of ${ }^{3} \mathrm{H}$-labelled thymidine incorporation into islet DNA was observed in the presence of approximately $1 \mu \mathrm{mol} / \mathrm{l}$ GABA and a maximal response was observed in the presence of $10 \mu \mathrm{mol} / \mathrm{l} \mathrm{GABA}$ (Fig. 5a). 
Fig. 2 Co-localisation of insulin and GABA B receptor subunits in pancreatic beta cells. Pancreas sections were examined by confocal microscopy using antibodies directed against (a) insulin and (b) GBR1-C. c Merged images from panels (a) and (b). Scale bar $=10 \mu \mathrm{m}$
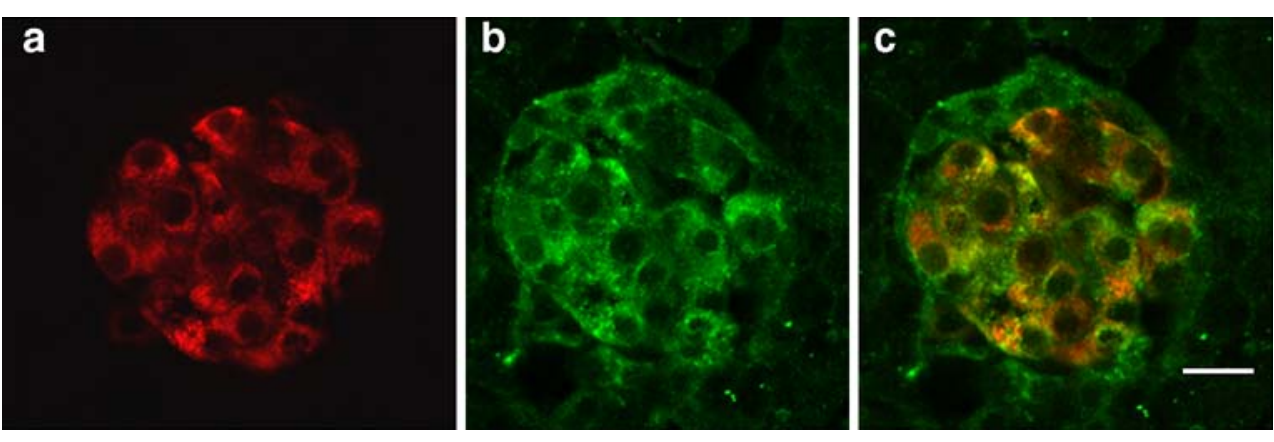

These data correlate with the pharmacological concentrations necessary for neurotransmission [34]. Similar to its effect on islet DNA content (Fig. 1), ${ }^{3} \mathrm{H}$-labelled thymidine incorporation into islet DNA was also increased when islets were incubated with the GABA B receptor agonist baclofen. The median effective concentration $\left(\mathrm{EC}_{50}\right)$ for this response to baclofen is approximately $600 \mathrm{nmol} / \mathrm{l}$ and a maximal response was noted when $1 \mu \mathrm{mol} / 1$ baclofen is present (Fig. 5b). The stimulatory effect of GABA was first apparent after a lag period of approximately $60 \mathrm{~min}$ and increased with longer exposure to GABA (Fig. 5c). The uptake of ${ }^{3} \mathrm{H}-$ labelled thymidine over the few hours of these experiments probably reflects the short cell cycle of beta cells, namely $14.9 \mathrm{~h}$ [35]. GABA exposure has also been shown to reduce the duration of each phase of the cell cycle in neural progenitors [13].

Finally, as shown in Fig. 6, GABA increased the rate of islet cell proliferation as measured by nuclear labelling with the nucleoside analogue BrdU. BrdU was included in the medium during and following $60 \mathrm{~min}$ exposure of islets to GABA. As noted by others [1, 33, 35], under resting conditions and without GABA, nuclear labelling with BrdU is infrequently observed (Fig. 6a). In contrast, nuclear labelling with BrdU was markedly increased in the presence of GABA $(100 \mu \mathrm{mol} / \mathrm{l})$ (Fig. 6b). Insulin-containing beta cells in rats are primarily located in the core of the islet (Fig. 6c) where BrdU nuclear labelling is prominent (Fig. 6d). Using a double labelling technique, many cells


Fig. 3 Pancreatic islet expression of GABA B receptor subunits. GABA B receptor subunits were localised by immunohistochemical analysis of whole pancreas. a, e Labelling using an antibody to GBR1 (anti-GRBI-N). b, f GBR2 immunohistochemical localisation (antiGBR2). c Merged image of panels (a) and (b). g Merged image of
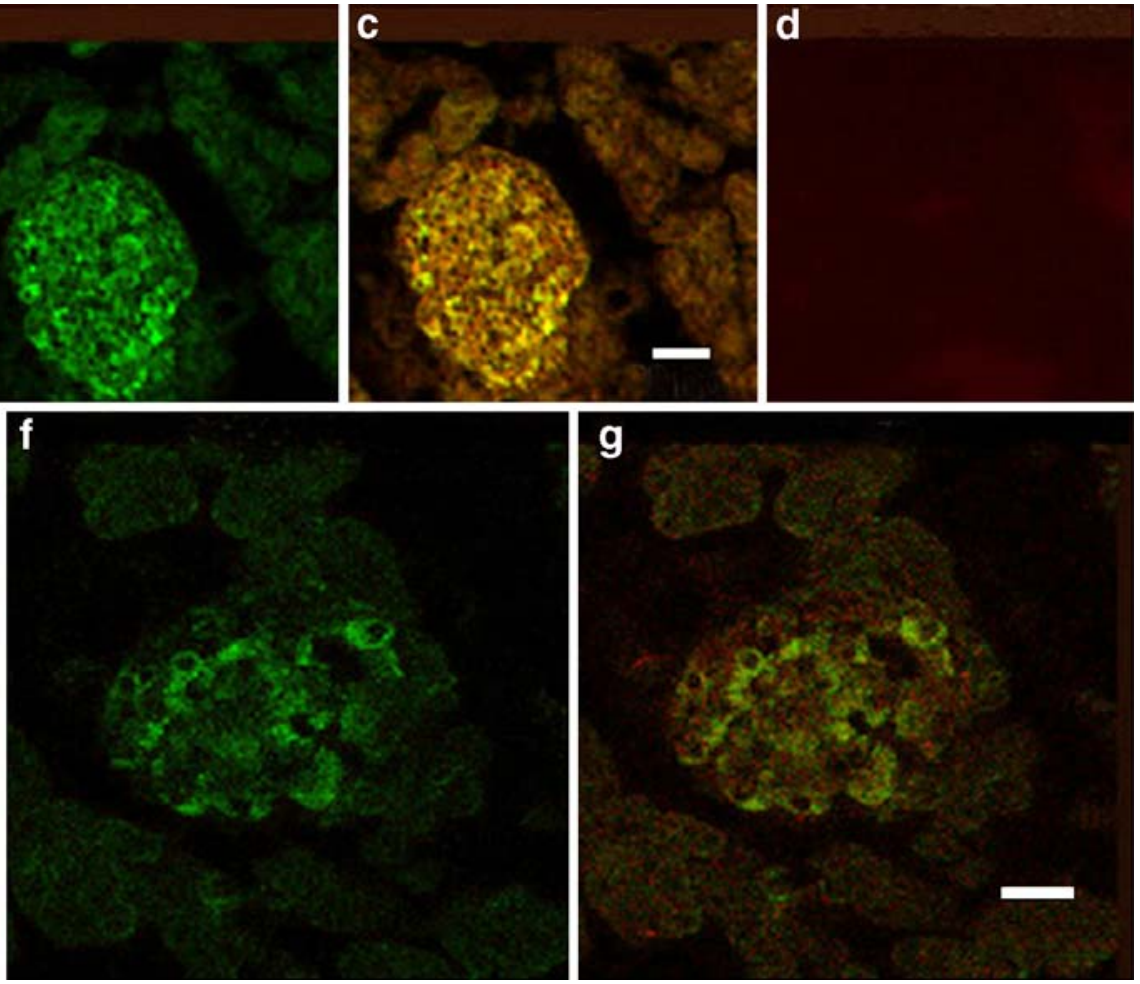

panels (e) and (f), demonstrating variable levels of production of GBR1 and GBR2. Islets exposed to excess peptide antigen along with the antibody for GBR1-N (PA-anti-GBR1-N) (d). Fluorescence microscopy. $\mathbf{e}-\mathbf{g}$ Confocal microscopy. Scale bars $=20 \mu \mathrm{m}$ 

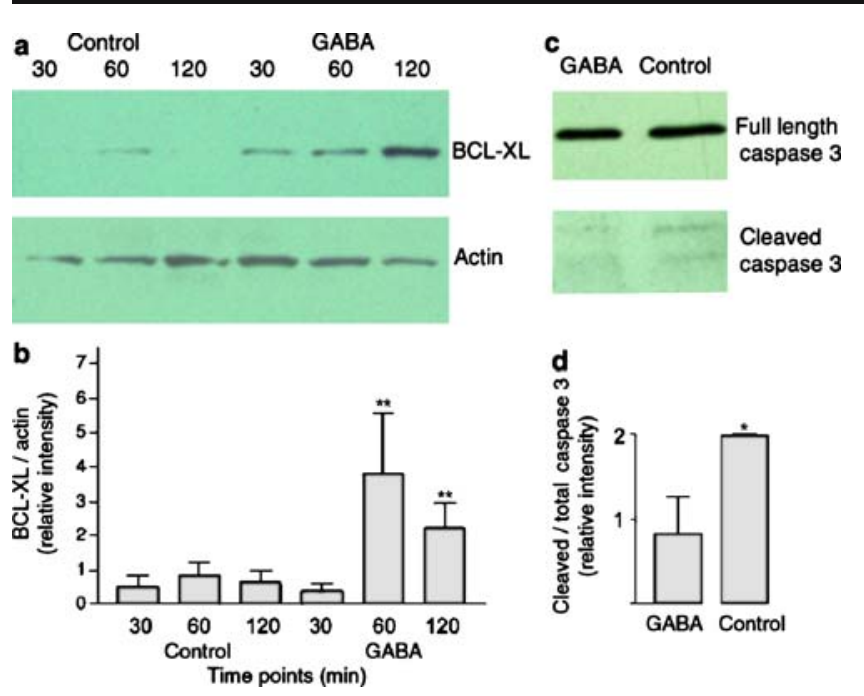

Fig. 4 GABA upregulates the anti-apoptotic protein BCL-XL and decreases active caspase 3. A representative immunoblot (a) of three experiments that demonstrate progressive increase of the antiapoptotic protein BCL-XL in islets treated with GABA for different lengths of time $(30,60,120 \mathrm{~min}$ as shown). b Histogram of BCL-XL immunoreactivity analysed by densitometry and compared with actin immunoreactivity; average of three experiments. c A representative immunoblot of three experiments that demonstrate a decrease of the activated, cleaved form of the pro-apoptotic protein caspase 3 in islets treated with GABA. Histogram (d) of cleaved caspase 3 immunoreactivity analysed by densitometry and compared with total caspase 3 immunoreactivity; average for three experiments. Error bars represent SEM. ${ }^{*} p<0.05 ; * * p<0.01$ compared with control values

demonstrating GABA-stimulated nuclear BrdU labelling were found to contain insulin. The rate of BrdU nuclear labelling induced by GABA was approximately double that observed in the absence of GABA (Fig. 6e), a rate similar in magnitude to that elicited by a known islet cell mitogen, hepatocyte growth factor [36] (Fig. 6e). These findings of increased labelling of dividing cells, especially in the core of the islet, support the notion that GABA plays a role in beta cell replication.

\section{Discussion}

Taken together, our results indicate an important role for GABA in protecting and replenishing pancreatic islet cells. Our results also implicate beta cells as a principal target of the GABA-induced biological effects, since we demonstrated: (1) the production of GABA B receptors on beta cells (as have others $[23,37])$; (2) the higher insulin content and secretion from islets exposed to GABA or baclofen; and (3) BrdU/insulin co-labelling in the core of treated islets.

This evidence, that GABA affects beta cells and activates compensatory mechanisms involved in their viability, suggests potential roles for GABA in the
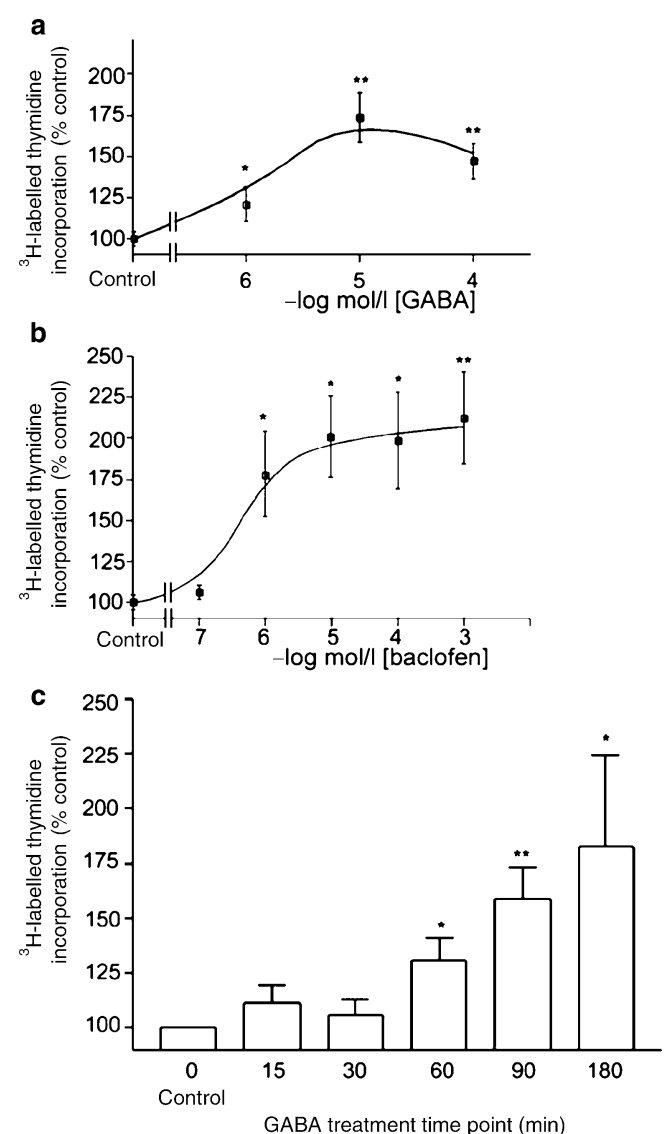

Fig. 5 GABA stimulates ${ }^{3} \mathrm{H}$-labelled thymidine incorporation into islet DNA. Freshly isolated islets were incubated with ${ }^{3} \mathrm{H}$-labelled thymidine $(0.037 \mathrm{MBq} / \mathrm{ml})$ and varying concentrations of either GABA (a) or baclofen (b) for $1 \mathrm{~h}$. They were then transferred to fresh medium without the test reagents and incubated for an additional $3.5 \mathrm{~h}$. The mean cpm for the controls was $2,511 \pm 237$ and 2,543 \pm 202 . c Time-dependence of GABA-stimulated ${ }^{3} \mathrm{H}$-labelled thymidine incorporation. Values are mean and SEM for four to six independent experiments. ${ }^{*} p<0.05 ; * * p<0.01$ compared with control values

treatment of diabetes. First, our finding that GABA treatment protected DNA and insulin content of isolated islets suggested to us that maintaining a critical concentration of GABA in the media during isolation and culture may provide a means to diminish the routinely observed cell loss occurring with these procedures prior to islet transplant. Second, these studies address issues of optimal islet transplant location and suggest that islets transplanted as a group under conditions of low flow would be more likely to sustain optimal levels of GABA. Islets that separate into individual cells or small cell clusters, or islets exposed to blood flow may not accumulate adequate GABA concentrations to activate survival programmes, accounting for some of the diminished function of transplanted islets observed over time [31]. Third, systemic restoration of GABA, particularly for patients with type 1 diabetes, may be a potentially important therapeutic strategy. Because beta cells are depleted in these patients by autoimmune attack, and in addition because GAD, the 

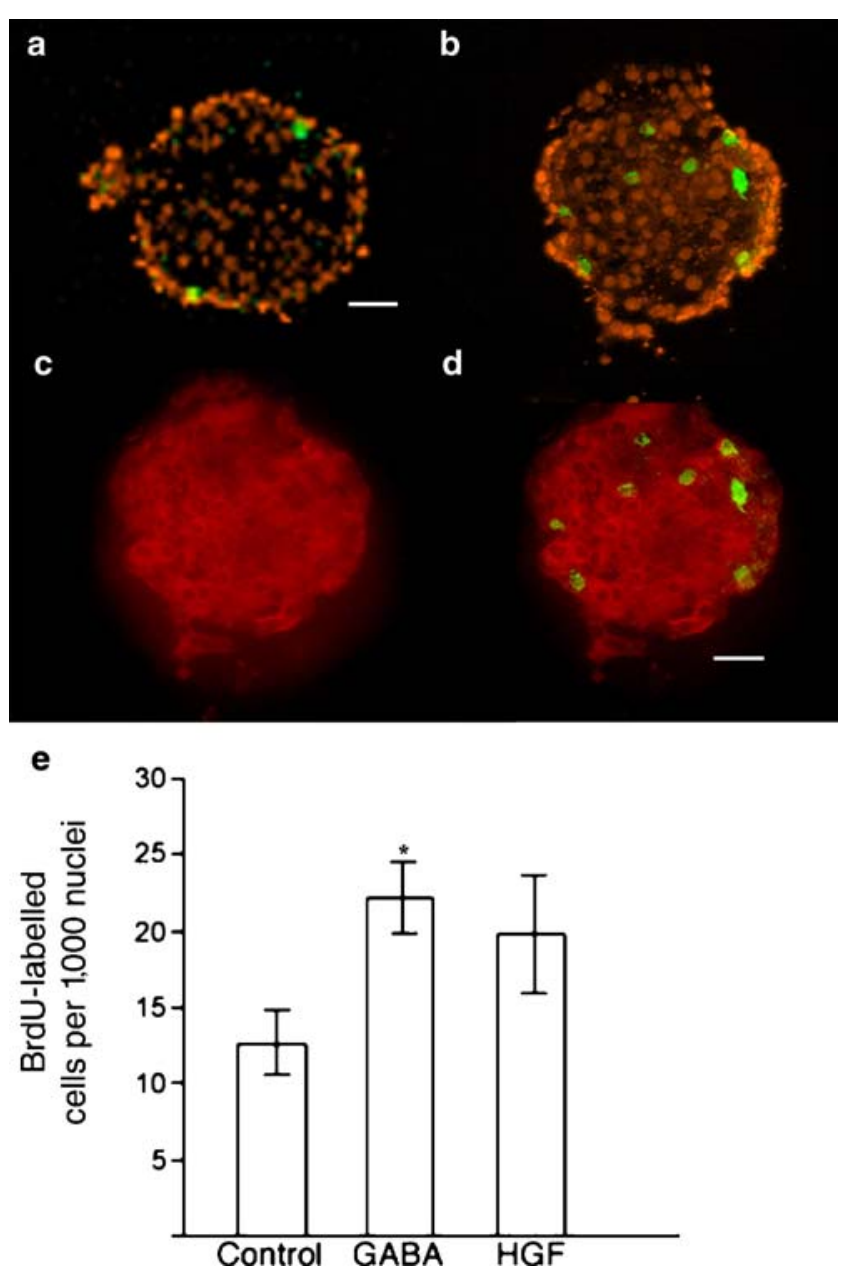

Fig. 6 GABA stimulated BrdU incorporation into islet DNA. Freshly isolated islets were incubated with BrdU, with or without GABA $(100 \mu \mathrm{mol} / \mathrm{l})$ or hepatocyte growth factor (HGF) $(20 \mathrm{ng} / \mathrm{ml})$ for $1 \mathrm{~h}$ and then cultured without GABA or HGF. a-d Fluorescence microscopy of: untreated sample (a), a sample incubated with GABA (b), the sample from panel (b) stained for insulin (red) (c), and (d) an overlay of insulin staining and BrdU. Green, BrdU; orange, propidium iodide nuclear stain; red, insulin. Scale bar $=25 \mu \mathrm{m}$. e Nuclear BrdU incorporation into islets that were incubated in the presence of GABA $(8,209$ nuclei) or HGF $(4,187$ nuclei) or in the absence of these agents (control, 5,663 nuclei). Results are from three independent experiments quantified by a treatment-blinded observer. ${ }^{*} p<0.05$ compared with control value by chi-square analysis. Values are means, error bars show SEM

principal GABA-synthesising enzyme, is an initial autoimmune target in this process, it is likely that GABA is severely reduced at an early stage of beta cell pathogenesis. Therefore, our in vitro findings that GABA exerts protective and proliferative affects raise the possibility that replenishing this amino acid in vivo may provide a means to maintain islet cell number and thereby maintain normal mechanisms of glucose control. This concept is supported by the in vivo findings of Beales et al., who administered the GABA B receptor agonist baclofen orally to non-obese diabetic mice, a model of type 1 diabetes, and found that the treatment significantly delayed the onset of diabetes
[38]. Moreover, Tian et al. found that sustained systemic GABA treatment suppressed diabetogenic $\mathrm{T}$ cells in the non-obese diabetic mouse, preventing diabetes onset [39] for up to a year in $>80 \%$ of treated mice. The possibility that GABA acts systemically raises the additional question of which diabetes complications could be ameliorated by restoring GABA levels.

An argument against a therapeutic role for GABA or baclofen on islets could be made on the basis of findings by Kash et al., indicating GABA is not essential for islet development, as islet mass was found to be normal in neonatal mice lacking genes encoding the GABA synthetic enzymes GAD65 and GAD67 [40]. However, an alternative interpretation of those results is that islets develop normally because GABA is present in the maternal circulation at concentrations of 0.580 to $4 \mu \mathrm{mol} / 1[20,41]$, near the $\mathrm{EC}_{50}$ value for GABA B receptor activation [34]. Therefore, maternally derived levels of GABA could suffice to activate fetal GABA receptors, preventing any deficiencies that might otherwise result. It is also likely that additional factors, such as lactogenic hormones [42], could support islet neogenesis during development, providing sufficient stimulus even in the absence of fetal-derived GABA.

To our knowledge, these studies are the first to demonstrate a GABA-induced effect on the apoptotic proteins BCL-XL and caspase 3, as well as on beta cell replication. This ability to suppress apoptosis and act as a mitogen indicates that GABA and its receptors may play a critical role in islet cell viability and function. Furthermore, given that physiologically relevant concentrations of GABA are present in the circulation, the question of systemic GABA actions arises, as well as the possibility that GABA, like insulin, activates trophic programmes in other organs. This premise is supported by findings that GABA is secreted from vesicles in a calcium-regulated manner [23, 43, 44], circulates in the blood stream at physiological concentrations [20, 41, 43] and activates effector systems through GABA receptors (both GABA A and GABA B) on many peripheral tissues $[37,39,43,45$ 50]. Avenues of GABA-related study appear to be plentiful and augur well for the possibility that additional comprehensive treatments for diseases like diabetes remain accessible.

Acknowledgements The authors thank Y. Chen for her technical assistance, J. Tatro and S. Roffler-Tarlov for critical comments on this manuscript and J. White for statistics expertise. This work was supported by Public Health Service grants K08-NS01923 and DK63344 (to B. Ligon), and by the Gastroenterology Research on Absorption and Secretion Program (DK34928 to B. Ligon) and the Surgery Department of Tufts-New England Medical Center.

Duality of interest None of the authors involved in this study had any duality of interest. 


\section{References}

1. Bernard-Kargar C, Ktorza A (2001) Endocrine pancreas plasticity under physiologic and pathological conditions. Diabetes 50(Suppl 1): S30-S35

2. Bonner-Weir S, Deery D, Leahy JL, Weir GC (1989) Compensatory growth of pancreatic beta-cells in adult rats after short-term glucose infusion. Diabetes 38:49-53

3. Bernard C, Berthault MF, Saulnier C, Ktorza A (1999) Neogenesis vs. apoptosis as main components of pancreatic beta cell mass changes in glucose-infused normal and mildly diabetic adult rats. FASEB J 13:1195-1205

4. Bouwens L, Rooman I (2005) Regulation of pancreatic beta-cell mass. Physiol Rev 85:1255-1270

5. Brockenbrough JS, Weir GC, Bonner-Weir S (1988) Discordance of exocrine and endocrine growth after $90 \%$ pancreatectomy in rats. Diabetes 37:232-236

6. Dor Y, Brown J, Martinez OI, Melton DA (2004) Adult pancreatic beta cells are formed by self-duplication rather than stem-cell differentiation. Nature 429:41-46

7. Ohsugi M, Cras-Méneur C, Zhou Y, Warren W, Bernal-Mizrachi E, Permutt MA (2004) Glucose and insulin treatment of insulinoma cells result in transcriptional regulation of a common set of genes. Diabetes 53:1496-1508

8. Owens DF, Kreigstein AR (2002) Is there more to GABA than synaptic inhibition? Nat Rev Neurosci 3:715-727

9. Shelp BJ, Bown AW, McLean MD (1999) Metabolism and functions of gamma-aminobutyric acid. Trends in Plant Sci 4:446-452

10. Gallego PP, Whotton L, Picton S, Grierson D, Gray JE (1995) A role for glutamate decarboxylase during tomato ripening: the characterization of a cDNA encoding a putative glutamate decarboxylase with a calmodulin-binding site. Plant Mol Biol 27:1143-1151

11. Palanivelu R, Brass L, Edlund AF, Preuss D (2003) Pollen tube growth and guidance is regulated by POP2, an Arabidopsis gene that controls GABA levels. Cell 114:47-59

12. Morse DF, Hooker N, Duncan H, Jensen L (1979) $\gamma$-Aminobutyric acid, a neurotransmitter, induces planktonic abalone larvae to settle and begin metamorphosis. Science 204:407-410

13. Haydar TF, Wang F, Schwartz ML, Rakic P (2000) Differential modulation of proliferation in the neocortical ventricular and subventricular zones. J Neurosci 20:5764-5774

14. Behar TN, Schaffner AE, Scott CA, O'Connell C, Barker JL (1998) Differential response of cortical plate and ventricular zone cells to GABA as a migration stimulus. J Neurosci 18:6378-6387

15. Maric D, Liu Q-Y, Maric I et al (2001) GABA expression dominates neuronal lineage progression in the embryonic rat neocortex and facilitates neurite outgrowth via $\operatorname{GABA}(\mathrm{A})$ autoreceptors/Cl channels. J Neurosci 21:2343-2360

16. Ikeda Y, Nishiyama N, Saito H, Katsuki H (1997) GABA $_{A}$ receptor stimulation promotes survival of embryonic rat striatal neurons in culture. Dev Brain Res 98:253-258

17. Fizman ML, Borodinsky LN, Neale JH (1999) GABA induces proliferation of immature cerebellar granule cells grown in vitro. Dev Brain Res 115:1-8

18. Meyerowitz EM (2002) Plants compared to animals: the broadest comparative study of development. Science 295:1482-1485

19. Gerber JC 3rd, Hare TA (1979) Gamma-aminobutyric acid in peripheral tissue, with emphasis on the endocrine pancreas: presence in two species and reduction by streptozotocin. Diabetes 28:1073-1076

20. Michalik M, Erecinska M (1992) GABA in pancreatic islets: metabolism and function. Biochem Pharm 44:1-9

21. Rorsman P, Berggren PO, Bokvist K et al (1989) Glucoseinhibition of glucagon secretion involves activation of GABAAreceptor chloride channels. Nature 341:233-236
22. Smismans A, Schuit F, Pipeleers D (1997) Nutrient regulation of gamma-aminobutyric acid release from islet beta cells. Diabetologia 40:1411-1415

23. Braun M, Wendt A, Birnir B et al (2004) $\mathrm{GABA}_{\mathrm{B}}$ receptor activation inhibits exocytosis in rat pancreatic beta-cells by G-proteindependent activation of calcineurin. J Gen Phys 123:191-204

24. Gaskins HR, Baldeon ME, Selassie L, Beverly JL (1995) Glucose modulates $\gamma$-aminobutyric acid release from the pancreatic BTC6 cell line. J Biol Chem 270:30286-30289

25. Wendt A, Birnir B, Buschard K et al (2004) Glucose inhibition of glucagon secretion from rat alpha cells is mediated by GABA released from neighboring $\beta$ cells. Diabetes 53:1038-1045

26. Gilon P, Bertrand G, Loubatières-Mariani MM, Remacle $\mathrm{C}$, Henquin JC (1991) The influence of $\gamma$-aminobutyric acid on hormone release by the mouse and rat pancreas. Endocrinology 129:2521-2529

27. Gu X-H, Kurose T, Kato S et al (1992) Suppressive effect of GABA on insulin secretion from the pancreatic beta-cells in the rat. Life Sci 52:687-694

28. White JH, McIllhinney RAJ, Wise A et al (2000) The GABA receptor interacts directly with the related transcription factors CREB2 and ATFx. Proc Natl Acad Sci USA 97:13967-13972

29. Nehring RB, Horikawa HPM, El Far O et al (2000) The metabotropic $\mathrm{GABA}_{\mathrm{B}}$ receptor directly interacts with the activating transcription factor 4. J Biol Chem 275:35185-35191

30. Heuss C, Scanziani M, Gahwiler BH, Gerber U (1999) G-proteinindependent signaling mediated by metabotropic glutamate receptors. Nature Neurosci 2:1070-1077

31. Cattan P, Berney T, Schena S et al (2001) Early assessment of apoptosis in isolated islets of Langerhans. Transplantation 71:857-862

32. Gotoh M, Maki T, Satomi S et al (1987) Reproducible high yield of rat islets by stationary in vitro digestion following pancreatic ductal or portal venous collagenase injection. Transplantation 43:725-730

33. Beattie GM, Montgomery AMP, Lopez AD et al (2002) A novel approach to increase human islet cell mass while preserving $\beta$ cell function. Diabetes 51:3435-3439

34. Kaupmann K, Malitschek B, Schuler V et al (1998) $\mathrm{GABA}_{\mathrm{B}^{-}}$ receptor subtypes assemble into functional heteromeric complexes. Nature 396:683-687

35. Swenne I (1992) Pancreatic beta-cell growth and diabetes mellitus. Diabetologia 35:193-201

36. Garcia-Ocaña A, Takane KK, Syed MA, Philbrick WM, Vasavada RC, Stewart AF (2000) Hepatocyte growth factor overexpression in the islet of transgenic mice increases beta cell proliferation, enhances islet mass, and induces mild hypoglycemia. J Biol Chem 275:1226-1232

37. Brice NL, Varadi A, Ashcroft SJH, Molnar E (2002) Metabotropic glutamate and GABA (B) receptors contribute to the modulation of glucose-stimulated insulin secretion in pancreatic beta cells. Diabetologia 45:242-252

38. Beales PE, Hawa M, Williams AJK, Albertini MC, Giorgini A, Pozzilli P (1995) Baclofen, a gamma-aminobutyric acid-b receptor agonist, delays diabetes onset in the non-obese diabetic mouse. Diabetologia 32:53-56

39. Tian J, Lu Y, Zhang H, Chau CH, Dang HN, Kaufman DL (2004) $\gamma$-Aminobutyric acid inhibits $\mathrm{T}$ cell autoimmunity and the development of inflammatory responses in a mouse type 1 diabetes model. J Immunol 173:5298-5304

40. Kash SF, Condie BG, Baekkeskov S (1999) Glutamate decarboxylase and GABA in pancreatic islets: lessons from knockout mice. Horm Metab Res 31:340-344

41. Biju MP, Pyroja S, Rajeshkumar NV, Paulose CS (2001) Brain stem GABA receptor functional regulation during rat liver cell proliferation. Mol Cell Biochem 216:65-70

42. Nielsen JH, Galsgaard ED, Moldrup A et al (2001) Regulation of $\beta$-cell mass by hormones and growth factors. Diabetes 50 (Suppl 1): S25-S29 
43. Minuk GY, Sarjeant EJ (1988) The effect of (a) neomycin and lactulose treatment on systemic and portal serum GABA levels in rats and (b) $\mathrm{pH}$ changes on $[3 \mathrm{H}] \mathrm{GABA}$ binding to isolated rat hepatocytes. Clin Invest Med 11:373-376

44. Reetz A, Solimena M, Matteoli M, Folli F, Takei K, De Camilli P (1991) GABA and pancreatic beta-cells: colocalization of glutamic acid decarboxylase (GAD) and GABA with synaptic-like microvesicles suggests their role in GABA storage and secretion. EMBO 10:1275-1284

45. Isomoto S, Kaibara M, Sakurai-Yamashita Y et al (1998) Cloning and tissue distribution of novel splice variants of the rat GABAB receptor. Biochem Biophys Res Commun 253:10-15

46. Calver AR, Medhurst AD, Robbins MJ et al (2000) Molecular cloning and characterization of a novel $\mathrm{GABA}_{\mathrm{B}}$-related G-protein coupled receptor. Neuroscience 100:155-170
47. Bowery NG, Bettler B, Froestl W et al (2002) International Union of Pharmacology XXXIII. Mammalian gamma-aminobutyric acid (B) receptors: structure and function. Pharmacol Rev 54:247-264

48. Chapman RW, Hey JA, Rizzo CA, Bolser DC (1993) GABA receptors in the lung. Trends Pharmacol Sci 14:26-29

49. Lehmann A, Antonsson M, Bremner-Danielsen M, Flardh M, Hansson-Branden L, Karrberg L (1999) Activation of the GABA (B) receptor inhibits transient lower esophageal sphincter relaxations in dogs. Gastroenterology 117:11471154

50. Weigert N, Schepp W, Haller A, Schusdziarra V (1998) Regulation of gastrin, somatostatin and bombesin release from the isolated rat stomach by exogenous and endogenous gammaaminobutyric acid. Digestion 59:16-25 